\title{
User-centered design through learner-centered instruction
}

\section{Burçak Altay}

To cite this article: Burçak Altay (2014) User-centered design through learner-centered instruction, Teaching in Higher Education, 19:2, 138-155, DOI: 10.1080/13562517.2013.827646

To link to this article: https://doi.org/10.1080/13562517.2013.827646

册 Published online: 19 Aug 2013.

Submit your article to this journal $₫$

Џ Article views: 952

View Crossmark data \lceil

Citing articles: 10 View citing articles $\sqsubset$ 


\title{
User-centered design through learner-centered instruction
}

\author{
Burçak Altay* \\ Department of Interior Architecture and Environmental Design, Bilkent University, \\ Ankara, Turkey
}

(Received 31 July 2012; final version received 2 July 2013)

\begin{abstract}
This article initially demonstrates the parallels between the learner-centered approach in education and the user-centered approach in design disciplines. Afterward, a course on human factors that applies learner-centered methods to teach user-centered design is introduced. The focus is on three tasks to identify the application of theoretical and methodological approach. The major instructional methods utilized in the tasks are role enactment, project-based learning, case-based learning and reflection. These tasks develop students' knowledge, attitude and skills reflecting on their selves, their social and physical environment. Finally, the results of the study on students' evaluations of the course and their learning are presented. The study findings indicate that the course has been successful in its learning objectives. Multiple methods of learner-centered instruction complement lecture sessions and one-another to enhance student learning of user-centered design in different levels of cognitive and affective domains.
\end{abstract}

Keywords: user-centered design; learner-centered instruction; human factors; design education

\section{Introduction}

One of the main problems in people's everyday quality of life is experiencing a mismatch between features of the built environment and products, with the actual needs and expectations of users. However, when designing spaces and products, constraints related to operation, materials, time, budget and many other factors often play a major role in the outcome. Due to these constraints, designers may overlook to incorporate information on users (Darses and Wolff 2006). Inadequate information particularly on users with diverse needs such as elderly, children, disabled and so on by designers may largely influence the design outcome leading to incompatible environments. In order to avoid this, a user-centered approach is suggested during the design process where the requirements, needs and expectations of users play a central and determining role.

\section{User-centered design and design education}

User-centered approaches to design enhance a wider range of diverse users to use and accept products/spaces, increasing productivity and reducing errors (Zoltowski,

\footnotetext{
*Email: burcak@bilkent.edu.tr 
Oakes, and Cardella 2012). The approach ensures more relevant design outcomes that go beyond mere utilitarian functionality, thus encourages user's emotional engagement and motivation by bringing their own conceptualizations and meanings to the experience (Krippendorff 2004; McDonagh and Thomas 2010).

A variety of user-centered research strategies can be identified during the design process (Kouprie and Visser 2009). For example, designers may have direct contact with the users through ethnographic methods of observation, shadowing, interviewing (McDonagh and Thomas 2010). Many architects apply these methods to integrate user needs into the design features of residential environments (Erman, Serpil-Altay, and Altay 2004). Designers also collaborate with users during the design process (Strickfaden and Devlieger 2011; Demirbilek and Demirkan 2004) and allow them to participate in design decisions. Additionally, designers may receive indirect scientific information about users through communication of userstudy research findings, storytelling, photography and original quotes. Finally, simulating user's condition by the designer can be applied (Cardoso and Clarkson 2012). This may be through role-playing, adoption of a certain capability loss or prototyping.

In endorsing designers' application of user-centered tools in professional practice in spite of client, time and cost constraints; their professional education plays a significant role. Education should expand students' knowledge of adequate data on human variety and transform their attitudes to account for inclusion.

Architectural, interior and industrial product design education centers around the 'design studio' where students are actively engaged with solving design problems throughout the semester. Although studio teaching and learning have extensively been discussed in literature (Öztürk and Türkkan 2006; Smith, Hedley, and Molloy 2009), there are fewer studies on courses included in the curriculum that support the design studio (Olguntürk and Demirkan 2009). Knowledge gained in the support courses can be applied at a variety of levels to design problems. One of such courses is human factors. Human factors or ergonomics 'applies theory, principles, data and other methods to design in order to optimize human well-being and overall system performance' (Human Factors and Ergonomics Society 2012). Understanding the interactions between people and their environments is central to the discipline where design criteria to increase quality of life ranges from safety, comfort and usability (Karwowski 2005). Therefore, human factors incorporate design-for-all, also designated as inclusive design or universal design. This aims for 'the design of products and environments to be usable by all people, to the greatest extent possible, without the need for adaptation or specialized design' (Center for Universal Design 1997).

International communities acknowledge the inclusion of a user-centered approach into the curricula of built environment professions. The Council of Europe (2001) suggests that universal design principles should be an essential part of education of architects, engineers, designers and town planners to ensure that citizens, regardless of their age, bodily variations and capabilities can participate to all aspects of society. The United States Department of Education (2013) also promotes the integration of universal design principles in all design-related disciplines. Moreover, through education/design policies and practices, it suggests the inclusion of all students equally to education in learning environments. Recently, Higher Education Council of Turkey (YÖK) also urged that the 'design-for-all' approach should nationally be integrated 
into the curricula of university departments including urban planning, landscape design, architecture, interior design and industrial design (Öztul et al. 2011).

While the necessity of integrating user-centered principles to design education is well established, how this can be achieved successfully needs further investigation of instruction methods. A study with engineering students on user-centered design revealed that immersive experiences for students including real clients and users allowed a more comprehensive understanding (Zoltowski, Oakes, and Cardella 2012). Another study showed that other than lectures and notes, students largely preferred practical exercises where human factors/ergonomics are integrated into design projects (Woodcock 2007). The emphasis on student experience in such studies suggests the application of learner-centered approaches for universal design instruction.

\section{Learner-centered instruction and its methods}

Learner-centered instruction embodies the application of a variety of methods that place the student at the center of education. As such, the teacher as a main source of knowledge shifts to knowledge gained from involvement of students. Rather than, or in addition to the transfer of knowledge through lectures where students are passive listeners, active learning through cooperation and collaboration are encouraged to increase students' self-relying capabilities, social and problem-solving skills (Wilson 2004). Students take the role of the 'actor' rather than the role of the 'receiver' (Svinicki and Dixon 1987). Learner-centered instruction is in parallel with experiential learning model that locates the student learning process in the organization of course activities (Kolb 1984).

Active learning methods can develop student learning in cognitive, affective and psychomotor domains; a framework of learning introduced by Bloom (1984). Cognitive domain relates to acquiring knowledge through developing cognitive processes in a hierarchical manner starting from lower order to higher order in the sequence of remembering, understanding, applying, analyzing, evaluating and creating (Krathwohl 2002). Affective domain relates to the transformation of students' attitudes with regard to a certain subject (Krathwohl, Bloom, and Masia 1964), thus resulting in an alteration of value systems. Psychomotor levels relate to the skills pertaining to the discipline. Bonwell and Sutherland (1996) suggest that different active learning strategies can be chosen based on specific goals set by the instructor depending on what they want the students to know (knowledge), feel (attitude) and able to do (skills). In that respect, Bonwell and Sutherland (1996) introduce a range of learner-centered methods to increase student engagement. Many of the methods are successfully utilized across disciplines and universities (Aditomo et al. 2011). From these, four of which are employed for user-centered design learning will be highlighted; enactment of practice, case-based learning, project-based learning and reflection.

\section{Enactment of practice}

Through enactment of practice, students enact roles that are significant to the profession (Aditomo et al. 2011). This may be done through role-playing where students take on roles of actors that resemble real-life situations or by simulation. 
Role-playing not only enhances the students to cope with situations related to real life, thereby initiating personal change, but also allows them to examine their positioning with respect to people in different situations promoting attitude change within the social context (Bonwell and Eison 1991).

Role-playing has been used in a variety of socio-physical settings. With the objective of teaching accessibility and universal design, role-playing by simulation of impairments increased the empathic understanding and affective learning for planning students (Lewis 2011) as well for architecture and occupational therapy students (Watchorn et al. 2013). Likewise, students from sociology (Livingston 2000) and geography (Treby, Hewitt, and Shah 2007) analyzed the campus environment according to accessibility standards to understand the social construction of ableism and difficulties of disabled students. Enactment through practice via theater was also utilized to achieve embodied knowledge of racism for white students (Sutherland 2013). In all of these courses, student feedback revealed that they gained an enhanced understanding of the subject that would be impossible through passive learning methods alone.

\section{Case-based learning}

Case-based learning takes place where students apply and exemplify the learned theoretical knowledge on real-life situations or cases, usually in groups (Kreber 2001; Aditomo et al. 2011). Application of acquired knowledge to the 'real-life problem', making recommendations/decisions or resolving conflicts, proposing alternative solutions or constructing their own frameworks are some of the tasks required from students. In that respect, case studies promote higher-order thinking for the students where they make decisions through analyzing, evaluating and creating. Moreover, students encounter human emotions and interactions inherent in the case studies; whereby 'this affective involvement leads to one of the most important advantages of case studies: changes in attitudes' (Bonwell and Eison 1991, 53).

The case method can be applied and delivered in a variety of time frames and media. It is adopted by many disciplines (Bonwell and Eison 1991) from law to business programs, with different emphasis on student learning. For example, analyzing case method applications in six different business schools revealed two different foci; the first being skill development through problem solving, while the second being conceptual development incorporating uncertainty in the cases leading to expand student cognitive learning (Rippin et al. 2002).

\section{Project-based learning}

In project-based learning, students are expected to work through problems to achieve an end product (Lee 2009). During the process, they encounter many small problems where they are expected to find solutions and proceed by the application of the gained knowledge (Aditomo et al. 2011). In terms of cognitive learning, creating a tangible outcome as a result of this application is usually desired.

Design disciplines utilize project-based methods in the design studios as a significant part of their curriculum. In design projects, the problems are ill defined where the solution space to the problem given is endless, thus promoting autonomy 
and authenticity in learning. Project types may range in having different foci in principles, structures and processes specific to the disciplines such as communication design, interior design and industrial design (Lee 2009). Project-based learning can successfully encompass user-centered tools. For example, a product design course was based on the collaborative work of disabled students from other disciplines with designer-students to come up with product solutions that enhanced the life quality for disabled students (McDonagh and Thomas 2010). Project-based methods accompanying the traditional lectures are also employed in engineering programs (Mills and Treagust 2003). With emphasis on learning rather than teaching, project-centered programs are suggested since students learn self-direction, manage their time and resources, therefore allowing a better preparation for professional practice.

\section{Reflection}

Reflection refers to students' learning through the transformation of their experience or action (Kreber 2001). Ryan (2013) points out two levels of reflection as making sense of the experience considering the self, others and the lived situation and being able to make projections to the future, so that what is learned can influence constructive future practices. Reflection may be achieved through tasks such as written reflections (logs, journals, etc.), visual reflections (sketches, posters, models), storytelling, discussion with peers and instructors.

In learner-centered instruction, learner's action and experience are supported through reflection. For example, reflective narratives and personal journals were utilized to increase empathic understanding of teachers with students having disabilities, in a teacher education program (Baglieri 2008). The main structure of the design studio is also based on reflection. Schön (1983) studied the dialog between instructor and student while discussing student projects (the design critique) revealing the reflective practice inherent in the process. Here, the situation is constantly reidentified and the student/designer is encouraged to reconsider what she or he has designed so far, to devise new strategies and reconstruct emerging problems/solutions continuing the process.

\section{The learner and the user: a common ground}

The studies above show that there are parallels between user-centered approach in design and learner-centered approach in education. These are primarily reflected on the self-identities of the designer/learner, their relationship with the social environment and physical environment.

- User-centered approach requires the designer to acquire a transformed understanding of the self and professional identity. Professional knowledge is shaped to adopt an inclusive approach within disciplinary practices. As the designer shifts his or her emphasis from a technology-centered design (Zoltowski, Oakes, and Cardella 2012) and abstract representations of users (McDonagh, Thomas, and Strickfaden 2011) to placing the user at the center of the design profession, the design practice reflects this change. The designer as such transforms during the design process, developing knowledge and 
restructuring values by constant feedback and critical reflection. Learnercentered education also promotes the active knowledge building by the student through concrete experiences during the learning process. Directly engaged in the process by doing meaningful activities and reflecting on what they are doing (Prince 2004), students' role shifts from passively receiving knowledge to actively contributing to the creation of knowledge, thus allowing for a personal transformation.

- User-centered design approaches promote the designer to engage in the social environment, promoting the development of designer empathy toward the user to increase awareness of how diverse people experience the environment. The designer role is placed aside as she or he steps into the shoes of others, through direct interaction with users, sharing life experiences, role enactment, interviews and user participation. Similarly, learner-centered approaches encourage experiencing the social environment through active participation in real-life situations as well as collaboration and cooperation with peers. This allows for the student to develop interpersonal skills and transform attitudes (Prince 2004). In both cases, the learning takes place through engagement with others in the social context, thus influencing the design/learning outcome.

- Designers have a constant interaction with the physical environment, shaping it through their design practices and being shaped by it through direct experience. They also acquire different views pertaining to the physical features by employing user-centered methodologies. This provides reflection on the design process and develops their design and creative skills, finally affecting the quality of the physical environment. Similarly, the learner is experiencing the physical environment through concrete experience and active experimentation in student-centered learning. The setting provides the context of learning rather than a passive backdrop, influencing the student skills and practices pertaining to the particular discipline.

\section{Learner-centered instruction in human factors course}

This section illustrates the application of learner-centered instructional methods adopting a user-centered approach within human factors course. It is a singlesemester course integrated into the second-year curriculum of Interior Architecture and Environmental Design Department of Bilkent University, Ankara. The focus of the learning objective is to develop students' knowledge (cognitive domain) and attitudes (the affective domain).

In a 15-week curriculum, for each learning unit, while the lectures intensely deliver theoretical aspects of the discipline with rich visual and explanatory examples; students expand their learning by active engagement to course material via concrete experiences through tasks (or assignments). Table 1 represents the course schedule with lecture subjects and corresponding tasks. The tasks are identified as course works or home works. Cognitive learning categories with respect to Bloom's taxonomy as revised by Krathwohl (2002) are highlighted in the task list. The learner-centered instructional method is also specified. In the following section, I focus on three sets of these assignments which are gray-highlighted in Table 1. 
Table 1. Human factors course lecture subject and task schedule (grey-highlighted tasks are discussed in this paper).

\begin{tabular}{|c|c|c|c|c|}
\hline Week & Lecture subject & Student task & $\begin{array}{c}\text { Coursel } \\
\text { Home } \\
\text { Wk }\end{array}$ & $\begin{array}{l}\text { Learner- } \\
\text { centered } \\
\text { instruction } \\
\text { method }\end{array}$ \\
\hline 1 & Definition, history of $\mathrm{HF}$ & & & \\
\hline 2 & Human diversity & $\begin{array}{l}\text { Analyzing own home for } \\
\text { wheelchair accessibility }\end{array}$ & HW & Case-based \\
\hline \multirow[t]{4}{*}{3,4} & Universal design & $\begin{array}{l}\text { Understanding the campus } \\
\text { through experience with } \\
\text { diverse abilities }\end{array}$ & $\mathrm{CW}$ & $\begin{array}{l}\text { Enactment of } \\
\text { practice }\end{array}$ \\
\hline & & $\begin{array}{l}\text { Written descriptions of } \\
\text { experience }+ \text { discussion in } \\
\text { class }\end{array}$ & $\mathrm{CW}$ & Reflection \\
\hline & & Creating a poster design & HW & Project-based \\
\hline & & Quiz on universal design & $\mathrm{CW}$ & \\
\hline 5 & $\begin{array}{l}\text { Static anthropometry, } \\
\text { workspace design }\end{array}$ & Analyzing a 'workspace': kiosk & HW & Case-based \\
\hline \multirow[t]{2}{*}{6,7} & Principles of seating & Creating a product design & HW & Project-based \\
\hline & & $\begin{array}{l}\text { Understanding and analyzing } \\
\text { seats by experiencing them; } \\
\text { evaluating with written form }\end{array}$ & $\mathrm{CW}$ & $\begin{array}{l}\text { Enactment of } \\
\text { practice, } \\
\text { reflection }\end{array}$ \\
\hline 8 & Midterm examination & & CW & \\
\hline 9 & Office spaces & Analyzing an office workspace & HW & Case-based \\
\hline 10 & Kitchens & Analyzing own kitchen & HW & Case-based \\
\hline 11 & Bathrooms, restrooms & Creating a public toilet design & HW & $\begin{array}{l}\text { Problem- } \\
\text { based, } \\
\text { Project-based }\end{array}$ \\
\hline 12 & Living rooms, bedrooms & Quiz on accidents in the home & $\mathrm{CW}$ & \\
\hline 13 & $\begin{array}{l}\text { Residential spaces, guest } \\
\text { lecturer }\end{array}$ & & & \\
\hline \multirow[t]{2}{*}{14} & Public spaces & $\begin{array}{l}\text { Case study: Student group } \\
\text { analyzing and evaluating a } \\
\text { public space, }\end{array}$ & HW & Case-based \\
\hline & & $\begin{array}{l}\text { Presentation and discussion in } \\
\text { class }\end{array}$ & $\mathrm{CW}$ & Reflection \\
\hline 15 & Final examination & & $\mathrm{CW}$ & \\
\hline
\end{tabular}

HW, home work; CW, course work.

Note: Cognitive learning processes in bold.

\section{Tasks related to universal design}

Within the course subject of 'Universal Design', the objective of the first set of tasks was to increase students' awareness of human diversity, after the delivery of a theoretical lecture on the subject.

The main method was enactment through practice by simulation in one 3-hour session of the course. Students explored the university in pairs, using wheelchairs, crutches, or blindfolds, switching between the helper and disabled person. They explored the accessibility of the campus environment and buildings, as shown in Figure 1. 

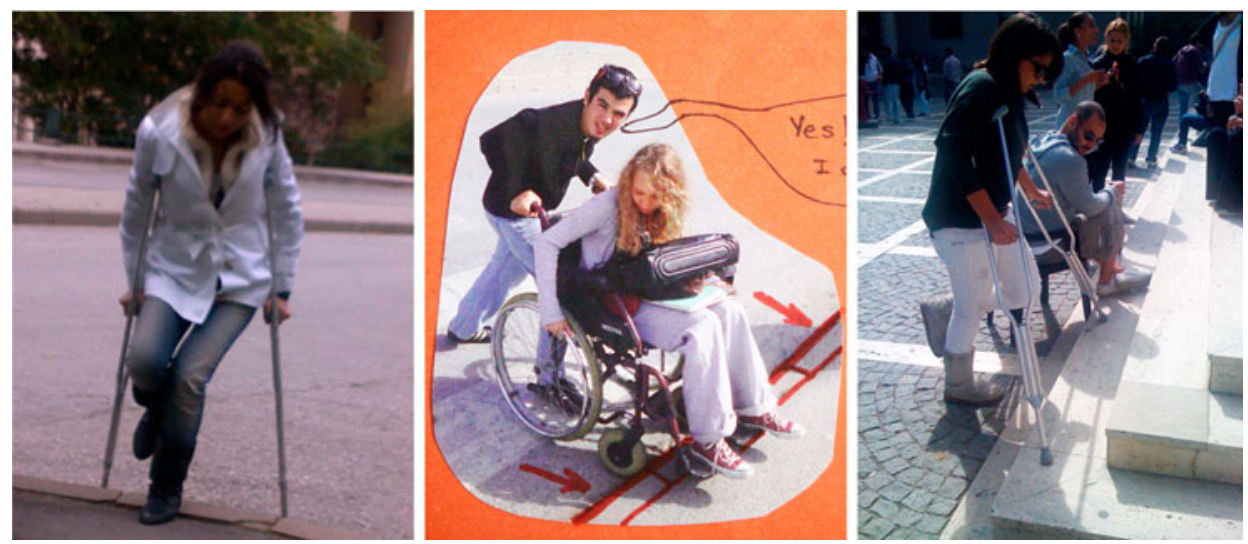

Figure 1. Students struggle with obstacles in the physical environment.

Following the experience, students provided written descriptions and a poster design to increase public awareness for universal design. A detailed analysis of students' written descriptions and posters regarding their cognitive and affective learning was carried out in another study (Altay and Demirkan 2013). This section will only highlight certain aspects emerging from this analysis; mainly student learning with respect to their selves, physical and social environment.

Through hands-on experience, the students gained an increased understanding of self-awareness. While they reported changes in their bodies such as requirement of strength, balance and so on, they were also concerned with how they were perceived by others. In that respect, the simulation technique proved really beneficial in providing affective link with the user, expanding beyond cognitive understanding. The following description by a student reflects the changes in her self-awareness engaging with the socio-physical environment:

When you lose your sight, you feel like time passing slower than usual; you feel like floating in space when you cannot sense your surroundings, you find that every sound is indeterminate because source is indeterminable, you need to feel for ground under your feet before every step, your hands are constantly wandering around to find something to guide you ... you are treated like a victim by others, you can feel how people around you pity you, you constantly feel inadequate.

With regard to the physical environment, many features such as stairs, ramps, doors were problematic for all of the students. Yet, the type of impairment and role within the experience influenced their views:

Balance is the major thing for crutch users, especially at stairs. To place the bottom of the crutch, the width of the stairs should not be so large; otherwise it is hard to jump from one stair to another. Also texture is crucial. If floor texture is too rough, it causes stability problems; if it is too smooth, it leads the crutches to slide. (crutch user)

If you are training in Interior Design department, being on a wheelchair becomes a torture!... Problems start at the entrance. After that you have to confront elevators, drafting tables, classrooms and restrooms. If you don't have a helper, you can only push the elevator button! (wheelchair user) 

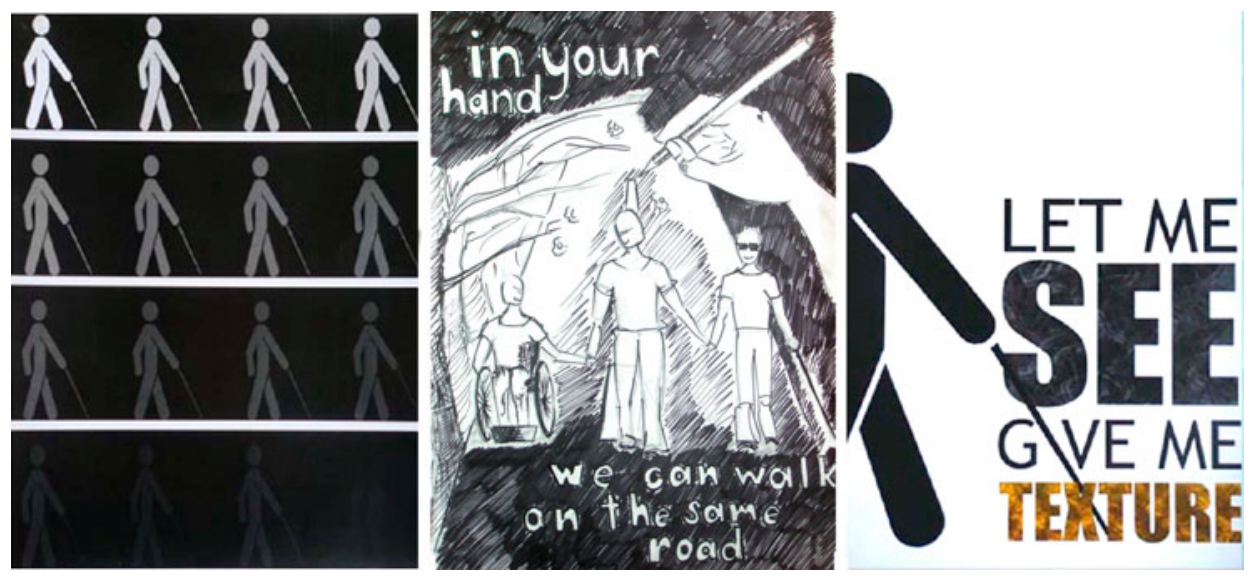

Figure 2. Posters designed by students.

The dependence of others to perform regular activities was also new to students, as was being the helper; both focusing on the challenges of social interaction:

Besides being the 'blind' person, being in place of the helper is also very challenging. Since the one next to you is as if moving in 'space' while moving around, guiding him and controlling his movements are difficult. You have to be very attentive since you carry your friend's responsibility. (blindfolded student helper)

Reflection on the simulation experience was possible through the class discussions and the follow-up poster design task. Students used their creative skills to achieve the objective of communicating the significance of universal/inclusive design with the larger population, sometimes focusing on knowledge acquisition, while at other times stressing on a call for attitude change. Figure 2 shows three posters designed by students, reflecting the affective social/emotional and cognitive components.

The first poster illustrates the visibility/invisibility of the person with impairment in our world. Therefore, it highlights the double impact of disability, both from the perspective of the public who fail to notice and from the disabled person whose voice is not heard. The second one draws upon the responsibility of the designer to provide inclusive environments and calls for her cooperation with diverse users. The third poster indicates the physical features required to help a blind person; knowledge the student gained from direct experience.

Overall, the direct impact of this assignment was visible in consequent assignments where students were more attentive to universal design features in their work.

\section{Tasks related to seating}

Within the course subject of 'Principles of Seating', the objective of the second set of assignments was to design a seating unit and evaluate the seats considering ergonomic criteria. The procedure was a 2 -week take-home project where students, in groups of two to three, designed and constructed a chair with materials such as cardboard, styrofoam, wire and so on. Figure 3 represents sample seating units. 

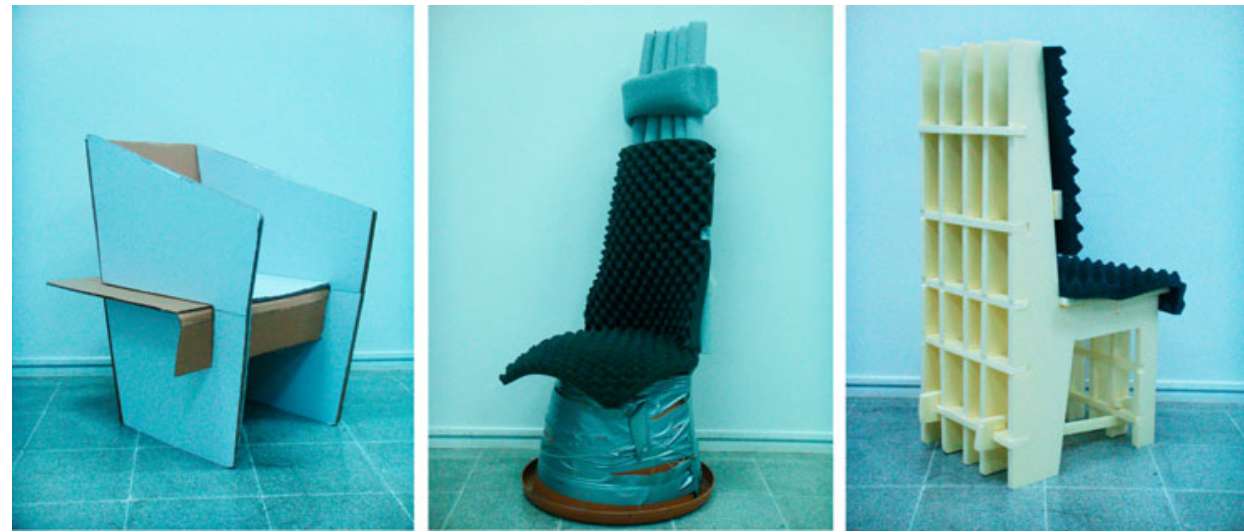

Figure 3. Seats designed and built by students.

Afterward, these were subject to testing and evaluation by students themselves during course hours as shown in Figure 4.

For evaluations, students filled out a form considering seating criteria based on Grandjean's (1973) studies on seat comfort depending on parameters such as height, depth, width, backrest contour and structural stability. This provided a useful link between theory and practice; where their actual experiences of comfort were systematically classified through formalized standards and criteria.

The students actively engaged in the task via design and use. It was principally project-based where they created seats applying the knowledge gained in the course, followed by enactment of practice where they adopted the role of users and tried the
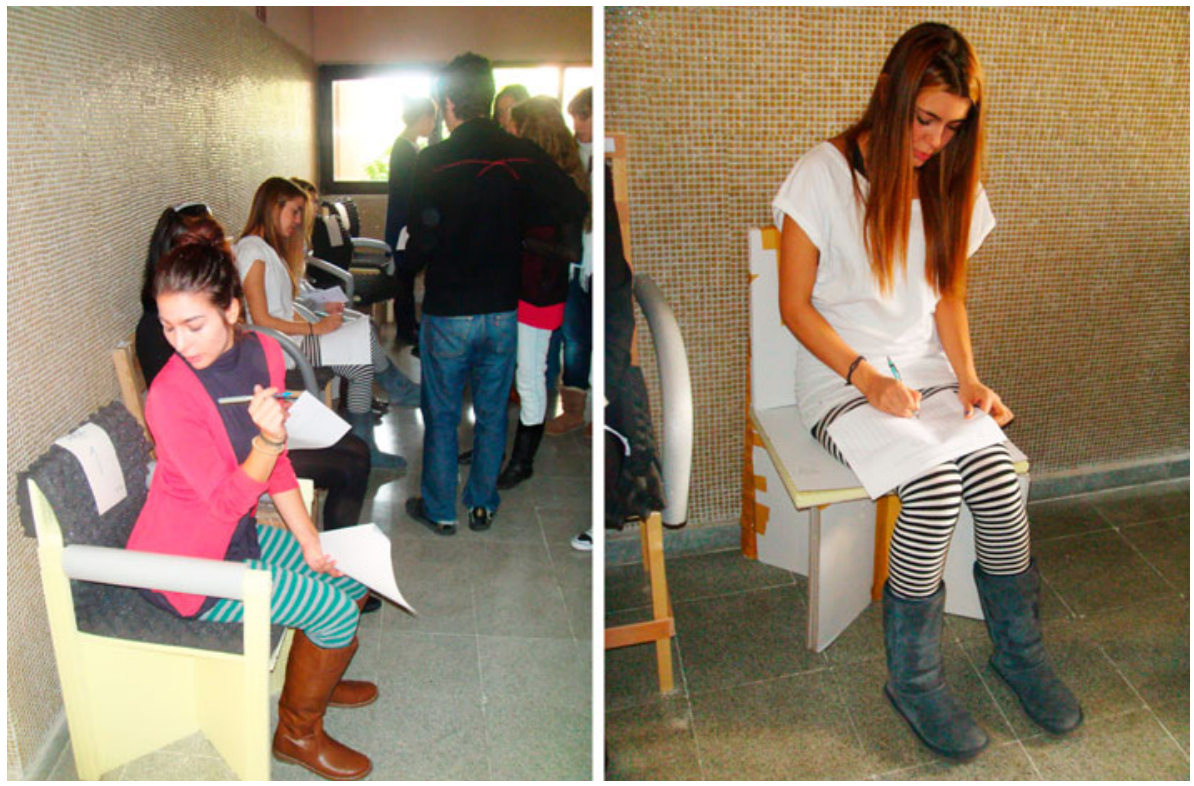

Figure 4. Students evaluate their own and friends' designs. 
products. The task was supported by reflective observation as students evaluated and documented the seating quality.

This exercise reconstructed the self-understanding of students since the three roles of designer, user and 'critic' were merged. While students compared their own as well as peers' seats, they discussed experienced problems, comfort levels and seat parameters. This was an opportunity for direct observation of the 'designer' of their 'user' in context (Kouprie and Visser 2009). The hands-on experience in creating the product and relating to it personally; as well as observing others' trials, formed a multilevel response to the complex relationship between human and environment. The students improved social skills through collaborative teamwork in project creation. The assignment also dissolved the teacher/student boundaries, shifting the responsibility and power from teacher to learner since students assessed their own products, a very critical aspect of student-centered learning (Barraket 2005). The task ended by an exhibition where the 'most comfortable seats' that the students identified were recognized, which reflected on instructor grading.

\section{Tasks related to public spaces}

The case study task was a sum-up of the semester where students were expected to present all the knowledge and understanding they gained throughout the course. The objective was to encourage students implement their human factors knowledge in the analysis and evaluation of a public space of their choice followed by the presentation of their work to the class. They were encouraged to select public spaces of different functions from the city, such as restaurants, nurseries, bookshops and cinemas. In that way, each group would learn from others' case studies through presentations, while a comparison of different/common activities and requirements would be possible.

The project was carried out in groups of three to four. This showed major benefits. First, they were able to observe the impact of diverse physiological characteristics in relationship to design. As one student remarked: 'Although I was able to reach the upper shelves, my friend who is in lower percentile in stature was not able to do so'. Second, the group-work enhanced cooperation among students, improved their parts in the group as well as their thinking and understanding through the process (Wilson 2004).

The format and design of the presentations was also students' responsibility. They were required to apply the universal design principle of 'perceptible-information', through the use of right fonts and colors, providing correct relationship with visuals and text and so on to convey the required messages. Through reflection during group presentations; students learned from each-others' works while the instructor took the role of facilitator, commenting on the presentations where required.

A social awareness of different populations took place since students considered users such as bulky men, petite women, blind people, wheel-chaired people, children and elderly in their case studies. They were able to apply the theoretical knowledge to interpret the features of the built environment according to the criteria of human factors. They were also able to observe and informally interview the people occupying the spaces, learning about their positive and negative views, adaptations and problems with increased empathic understanding. The process increased students' evaluative skills toward physical factors as they critiqued design mistakes 

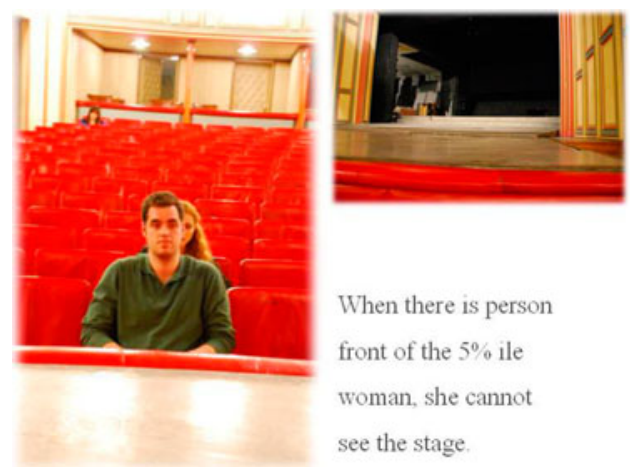

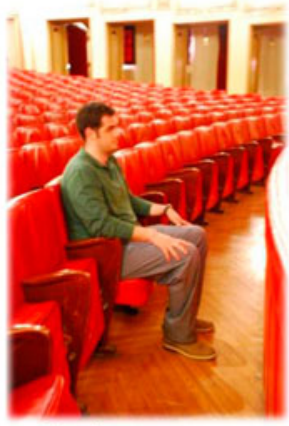

Forefront seats

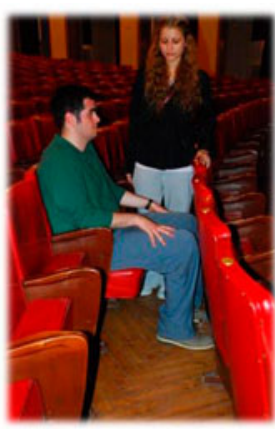

Back seats

Figure 5. In an opera house, students demonstrate passageway and visibility opportunities according to different user populations.

and provided suggestions. Figures 5 and 6 are sample slides from students' presentations covering a wide range of public spaces, activities and users.

\section{Students assess their learning in the course}

In order to investigate the students' perceptions of their learning experience in the course, a research was conducted. A written questionnaire was handed to the students to be completed, voluntarily, in 20 minutes of allocated time before their final examinations in the classroom. The students were clearly informed that the survey was for education/research purposes as well as for course improvement and would not have any impact on their grading. They were not required to write their names on the forms.

\section{Research questions and procedure}

In the spring 2011 semester, of the 62 students, a total of 59 students who participated in the two course sections answered the survey ( $95 \%$ response rate). Research questions that were explored through the survey were

\section{DINING HALL}

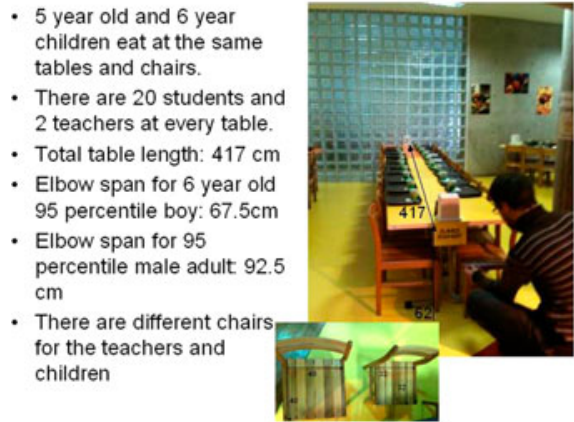

PLAY AREA

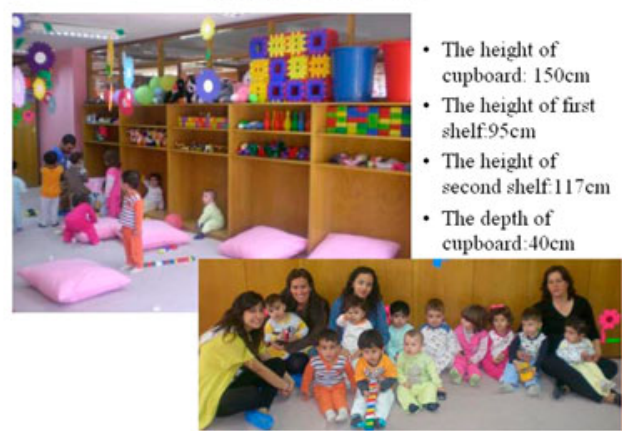

Figure 6. Students analyze two different nurseries according to ergonomic criteria, also interacting with users. 
(1) to what extent did the students' cognitive learning of human factors knowledge take place; particularly developing understanding/awareness, analysis, evaluation and creating/design?

(2) what was the effect of different type of instructional methods on student learning; in both cognitive and affective domains?

\section{Findings}

To explore the first research question, the students were asked three closed-ended questions on a 5-point scale. They were required to indicate their answer from 1 to 5, 1 indicating 'not at all', 2 indicating 'very little', 3 indicating 'moderately', 4 indicating 'greatly' and 5 indicating 'extremely'. The first question explored the influence of the course to their understanding and awareness, analysis and evaluation, and design of spaces/environments. The second question explored the impact of the course to the design studio, where they carry out interior design projects. The third question explored the difference of their knowledge accumulation prior to and after the course. Table 2 summarizes the findings.

Students believe that this course was influential in developing a variety of cognitive processes. They also view that the course affected their performance in the design studio. This is a critical finding since it points the direction toward the influence of the course in design practices when they graduate to become professionals, which is one of the main objectives. Moreover, they consider that the extent of their knowledge has increased after having taken the course.

To explore the second research question, two questions were asked. The first question explored, in general, the success of various teaching methods adopted in the course, with the exclusion of final exam since survey was held prior to the exam. This was also a closed-ended question on a 5-point scale. Table 3 presents the results.

The striking finding from the students' views is that they believe having learned from lectures much more than any other method of teaching, followed by the case

Table 2. Student assessment of course learning outcomes.

\begin{tabular}{|c|c|c|}
\hline Questions & $\begin{array}{c}\text { Mean } \\
\text { (between } \\
1 \text { and 5)* }\end{array}$ & $\begin{array}{l}\text { Standard } \\
\text { deviation }\end{array}$ \\
\hline \multicolumn{3}{|l|}{$\begin{array}{l}1 \text { - To what extent taking human factors (HF) course } \\
\text { enhance the following skills for you? }\end{array}$} \\
\hline $\begin{array}{l}\text { 1a - Understanding and awareness of HF and universal design } \\
\text { (UD) subjects }\end{array}$ & 4.52 & 0.73 \\
\hline $1 \mathrm{~b}-$ Analysis and evaluation of spaces/products & 4.52 & 0.69 \\
\hline 1c - Design of spaces/products & 4.33 & 0.83 \\
\hline $\begin{array}{l}2 \text { - To what extent has the knowledge/skills you have gained } \\
\text { positively affect your design projects in the design studio? }\end{array}$ & 4.29 & 1.15 \\
\hline $\begin{array}{l}3 \mathrm{a} \text { - What was the extent of your knowledge of } \mathrm{HF} \text { and UD } \\
\text { at the beginning of the semester before the course? }\end{array}$ & 3.02 & 0.62 \\
\hline $\begin{array}{l}3 \mathrm{~b}-\text { What has been the extent of your knowledge of HF } \\
\text { and UD after taking the course? }\end{array}$ & 4.41 & 0.65 \\
\hline
\end{tabular}

$* 1=$ not at all, $2=$ very little, $3=$ moderately, $4=$ greatly, $5=$ extremely. 
Table 3. Student evaluations of teaching/assessment methods.

\begin{tabular}{lccc}
\hline Question: Which teaching/assessment methods were & $\begin{array}{c}\text { Mean } \\
\text { Raccessful in increasing your understanding/awareness/ } \\
\text { analytic and design skills on the subject? }\end{array}$ & $\begin{array}{c}\text { (between } \\
\text { and 5)* }\end{array}$ & $\begin{array}{c}\text { Standard } \\
\text { deviation }\end{array}$ \\
\hline 1 & Lectures & 4.36 & 1.13 \\
2 & Case-study & 4.15 & 1.06 \\
3 & Midterm exam & 3.85 & 0.96 \\
4 & Course-works & 3.81 & 1.10 \\
5 & Homeworks & 3.53 & 1.03 \\
6 & Quiz & 2.98 & 0.91 \\
\hline
\end{tabular}

$* 1=$ not at all, $2=$ very little, $3=$ moderately, $4=$ greatly, $5=$ extremely.

study project. This is understandable since they acquire the basic theoretical knowledge from the lectures, which comprise a high percentage of the course time. It also implies that learner-centered instruction may not be adequate to cover all aspects of a unit and multiple instructional methods complementing each other are necessary. One drawback of the questionnaire that reflected to the results was that the individual course works and home works were not itemized; which would let us observe their impact on student learning separately.

The second question inquiring the effect of instructional methods was openended. The students were asked to mark three favorite tasks completed throughout the course, without any special order. They were also required to explain briefly the reasons of their favorite choices. The frequency of choices for each task was documented quantitatively as shown in Table 4.

The results reveal that the task related to public spaces is one of the most successful among others. This is surprisingly followed by the task related to bathrooms, which consists of a design of public toilets. The third most mentioned favorite is the simulation experience.

The reasons of preferences were grouped together to receive an overview of the students' perspective. For example, students wrote that the case study task enabled them to analyze and examine thoroughly an interior space expanding their critical understanding via in-group discussions about significant issues. Some also noted that the task enabled them to view the environments that they already inhabited from a new perspective, strengthening their self-confidence.

The public restroom design exercise required students to solve a public restroom design for men and women in a predetermined space. They were asked to complete the task within a 3-hour course session, whereas their solutions were discussed the next session. The reason of the task's success was its positive reflection to student projects in the design studio. The difficulties they encountered in the design projects were understood and resolved during this session, and they developed similar solutions in the studio project.

The major reasons of favoring the simulation experience were indicated to be the students' ability to see the environment from the eyes of the diverse user; hence putting oneself in other's shoes. Learning the significance of universal design principles by actually living them and expanding their empathic horizons accordingly were stated. 
Table 4. Student 'favorite' assignments.

\begin{tabular}{|c|c|c|c|c|c|}
\hline Rank & Wk & Lecture subject & Related assignment & $\begin{array}{l}\text { Number } \\
\text { of students } \\
\text { (of the 59) }\end{array}$ & $\begin{array}{l}\text { Percentage of } \\
\text { students }\end{array}$ \\
\hline 1 & 14 & Public spaces & $\begin{array}{l}\text { Case study: Student group } \\
\text { analyzing and evaluating a } \\
\text { public space, class presentation }\end{array}$ & 29 & 49 \\
\hline 2 & 11 & $\begin{array}{l}\text { Bathrooms and } \\
\text { public restrooms }\end{array}$ & Creating a public toilet design & 27 & 46 \\
\hline 3 & 3,4 & Universal design & $\begin{array}{l}\text { Understanding the campus } \\
\text { with diverse abilities, creating a } \\
\text { poster design }\end{array}$ & 23 & 39 \\
\hline 4 & 9 & Office spaces & Analyzing an office workspace & 21 & 36 \\
\hline 5 & 6,7 & Principles of seating & $\begin{array}{l}\text { Creating a product design, } \\
\text { understanding, analyzing seats; } \\
\text { evaluating in written form }\end{array}$ & 19 & 32 \\
\hline 6 & 2 & Human diversity & $\begin{array}{l}\text { Analyzing own home for } \\
\text { wheelchair accessibility }\end{array}$ & 19 & 32 \\
\hline 7 & 10 & Kitchens & Analyzing own kitchen & 15 & 25 \\
\hline 8 & 5 & $\begin{array}{l}\text { Static } \\
\text { anthropometry, } \\
\text { workspace design }\end{array}$ & Analyzing a 'workspace': kiosk & 14 & 24 \\
\hline
\end{tabular}

Note: Cognitive learning processes are in bold.

An interesting point that comes forth from the 'favorites' is that the exercises comprise a multitude of cognitive processes; the campus experience mainly contributing to understanding and comprehension, the case study contributing to analysis and evaluation and the toilet design contributing to creation. They also apply different forms of instruction. The case study method is applied for analyzing public spaces; enactment of practice through stimulation is applied in the campus experience and project-based problem-based methods are utilized for toilet design. Thus, a rich set of student learning processes seems to be nourished by complementary methods of instruction.

\section{Conclusion}

Human factors course within the Interior Design curriculum incorporated a wide range of methods to involve students' participation. Educational paradigms promoting engagement with the subjects, relating to real-life experiences through 'cooperation' and 'active learning' (Wilson 2004) has been combined with techniques to adopt a user-centered approach to design. Students' initial point of self-referencing as a basis for design, and the stereotyping of 'standard' user were altered with simulation of people of diverse abilities, creation of products/spaces, analysis and evaluation of the user environment interaction in diverse settings. Their repertoire of the 'user' thus expanded to reflect the multiplicity and dissimilarity of the population, including people with different abilities, anthropometric characteristics, age groups and so on. The assignments were complemented with reflective exercises where students continued their engagement with their experience through discussions, written texts, designs and analyses, all of which they shared with their peers. 
Students' evaluations of the course indicate that they appreciated a variety of instructional methods since this strengthened learning in both cognitive and affective domains. The students were also able to apply what they learned in other courses; particularly the design studio course. Consequently, different methods supporting lecture courses had impact on analytical, evaluative and creative skills as well as an increased empathy and emotional connection with diverse users.

Both user-centered education (McDonagh, Thomas, and Strickfaden 2011; Watchorn et al. 2013) and benefits of student-centered learning (Aditomo et al. 2011; Mills and Treagust 2003; Prince 2004; Barraket 2005) across disciplines are discussed in literature independently. This study contributes both to fields of design and education by providing a connection between user-centered approach in design and learner-centered approach in education. The article provides a relation between what is learned; the students cognitive and affective learning; with how it is learned, through varying learner-centered methods. Rather than passive learning, knowledge is constructed and transformed through the interaction of the designer/student within the 'learning environment' shaping one's own professional identity and role respectfully. As such, the learning environment consists of social factors where the designer/student has immediate connection with, and learns from others; that is users and peer students. It also necessarily involves physical factors which the designer/ student explores, experiments, observes the engagement of self and others; evaluates and participates in its creation. As such, both the advancement of knowledge in different levels of thinking and an alteration in attitudes regarding one's own responsibilities toward others occurs. Many disciplines that place the human at its center of concern can benefit from the utilization of a variety of instructional methods that place students within the center of instruction. Such an approach encourages students to adopt different roles, enrich their perspectives as they actively engage with and reflect upon the course material.

\section{References}

Aditomo, A., P. Goodyear, A. Bliuc, and R. Ellis. 2011. "Inquiry-Based Learning in Higher Education: Principal Forms, Educational Objectives, and Disciplinary Variations." Studies in Higher Education. doi:10.1080/03075070.2011.616584.

Altay, B., and H. Demirkan. 2013. "Inclusive Design: Developing Students' Knowledge and Attitude Through Empathic Modelling." International Journal of Inclusive Education. doi:10.1080/13603116.2013.764933.

Baglieri, S. 2008. "I Connected': Reflection and Biography in Teacher Learning Toward Inclusion." International Journal of Inclusive Education 12 (5-6): 585-604. doi:10.1080/ 13603110802377631.

Barraket, J. 2005. "Teaching Research Method Using Student-Centered Approach? Critical Reflections on Practice." Journal of University Teaching and Learning Practice 2 (2). Accessed February 12, 2013. http://ro.uow.ed.au/jutlp/vol2/iss2/3.

Bonwell, C. C., and J. A. Eison. 1991. Active Learning; Creating Excitement in the Classroom. ASHE-ERIC Higher Education Report No. 1. Washington, DC: The George Washington University, School of Education and Human Development.

Bonwell, C. C., and T. E. Sutherland. 1996. "The Active Learning Continuum: Choosing Activities to Engage Students in the Classroom." New Directions for Teaching and Learning 67 (2): 3-16. doi:10.1002/t1.37219966704.

Bloom, B. S. 1984. Taxonomy of Educational Objectives. Boston, MA: Allyn and Bacon. 
Center for Universal Design. 1997. The Principles of Universal Design, Version 2.0. North Carolina State University. Accessed January 14, 2011. http://www.ncsu.edu/www/ncsu/ design/sod5/cud/about_ud/udprinciplestext.htm.

Council of Europe. 2001. Resolution ResAP (2001)1 on the Introduction of the Principles of Universal Design into the Curricula of All Occupations Working on the Built Environment. Brussels: Council of Europe.

Cardoso, C., and P. J. Clarkson. 2012. "Simulation in User-Centred Design: Helping Designers to Empathize With Atypical Users." Journal of Engineering Design 23 (1): 122. doi:10.1080/09544821003742650.

Darses, F., and M. Wolff. 2006. "How do Designers Represent Themselves the Users' Needs?" Applied Ergonomics 37 (6): 757-764. doi:10.1016/j.apergo.2005.11.004.

Demirbilek, O., and H. Demirkan. 2004. "Universal Product Design Involving Elderly Users: A Participatory Design Model." Applied Ergonomics 35 (4): 361-370. doi:10.1016/j.apergo. 2004.03.003.

Erman, T., B. Serpil-Altay, and C. Altay. 2004. "Architects and the Architectural Profession in the Turkish Context." Journal of Architectural Education 58 (2): 46-53. doi:10.1162/ 1046488042485394.

Grandjean, E. 1973. Ergonomics of the Home. London: Taylor and Francis.

Human Factors and Ergonomics Society. 2012. Human Factors and Ergonomics Society. Accessed December 22, 2012. http://www.hfes.org//Web/AboutHFES/about.html.

Karwowski, W. 2005. "Ergonomics and Human factors: The Paradigms for Science, Engineering, Design, Technology and Management of Human-Compatible Systems." Ergonomics 48 (5): 436-463. doi:10.1080/00140130400029167.

Kolb, D. 1984. Experiential Learning: Experience as the Source of Learning and Development. Englewood Cliffs, NJ: Prentice Hall.

Kouprie, M., and F. S. Visser. 2009. "A Framework for Empathy in Design: Stepping Into and Out of the User's Life." Journal of Engineering Design 20 (5): 437-448. doi:10.1080/ 09544820902875033.

Krathwohl, D. R. 2002. "A Revision of Bloom's Taxonomy: An Overview." Theory into Practice 41 (4): 212-218. doi:10.1207/s15430421tip4104_2.

Krathwohl, D. R., B. S. Bloom, and B. B. Masia. 1964. Taxonomy of Educational Objectives, Book II. Affective Domain. New York: David McKay.

Kreber, C. 2001. "Learning Experientially Through Case Studies? A Conceptual Analysis." Teaching in Higher Education 6 (2): 217-228. doi:10.1080/13562510120045203.

Krippendorff, K. 2004. "Intrinsic Motivation and Human-Centred Design." Theoretical Issues in Ergonomics Science 5 (1): 43-72. doi:10.1080/1463922031000086717.

Lee, N. 2009. "Project Methods As the Vehicle For Learning in Undergraduate Design Education: A Typology." Design Studies 30 (5): 541-560. doi:10.1016/j.destud.2009.03.002.

Lewis, J. L. 2011. "Student Attitudes Toward Impairment: An Assessment of Passive and Active Learning Methods in Urban Planning Education." Teaching in Higher Education 16 (2): 237-249. doi:10.1080/13562517.2010.524921.

Livingston, K. 2000. "When Architecture Disables: Teaching Undergraduates to Perceive Ableism in the Built Environment." Teaching Sociology 28 (3): 182-191. doi:10.2307/ 1318988.

McDonagh, D., and J. Thomas. 2010. "Disability + Relevant Design: Empathic Design Strategies Supporting More Effective New Product Design Outcomes." The Design Journal 13 (2): 180-198. doi:10.2752/175470710X12735884220899.

McDonagh, D., J. Thomas, and M. Strickfaden. 2011. "Empathic Design Research: Moving Towards a New Mode of Industrial Design Education." Design Principles and Practices: An International Design Journal 5 (4): 301-314.

Mills, J. E., and D. F. Treagust. 2003. "Engineering Education: Is Problem-Based or ProjectBased Learning the Answer?" Australian Journal of Engineering Education. Accessed February 15, 2013. http:/www.aaee.com.au/journal/2003/mills_treagust03.pdf.

Olguntürk, N., and H. Demirkan. 2009. "Ergonomics and Universal Design in Interior Architecture Education." METU Journal of the Faculty of Architecture 26 (2): 123-138. doi:10.4305/METU.JFA.2009.2.7. 
Öztul, A. E., C. Girgin, O. Tutal, and M. Ö. Atay, eds. 2011. Herkes için tasarım müfredatı gelistirme çalistay sonuc raporu [Design-for-all Curriculum Development Workshop' Organized by Higher Education Council of Turkey and Anadolu University]. Accessed January 20, 2013. http://hertas.anadolu.edu.tr/calistay_hertas_eskisehir2011_sonucraporu. pdf.

Öztürk, M. N., and E. E. Türkkan. 2006. "The Design Studio as Teaching/Learning Medium A Process Based Approach." International Journal of Art and Design Education 25 (1): 96104. doi:10.1111/j.1476-8070.2006.00472.x.

Prince, M. 2004. "Does Active Learning Work? A Review of the Research." Journal of Engineering Education 93 (3): 223-231. doi:10.1002/j.2168-9830.2004.tb00809.x.

Rippin, A., C. Booth, S. Bowie, and J. Jordan. 2002. "A Complex Case: Using the Case Study Method to Explore Uncertainty and Ambiguity in Undergraduate Business Education." Teaching in Higher Education 7 (4): 429-441. doi:10.1080/135625102760553928.

Ryan, M. 2013. "The Pedagogical Balancing Act: Teaching Reflection in Higher Education." Teaching in Higher Education 18 (2): 144-155. doi:10.1080/13562517.2012.694104.

Schön, D. 1983. The Reflective Practitioner. San Francisco, CA: Jossey-Bass.

Smith, D., P. Hedley, and M. Molloy. 2009. "Design Learning: A Reflective Model." Design Studies 30 (1): 13-37. doi:10.1016/j.destud.2008.06.002.

Strickfaden, M., and P. Devlieger. 2011. "Empathy Through Accumulating Techné: Designing an Accessible Metro." The Design Journal 14 (2): 207-229. doi:10.2752/175630611X 12984592780041.

Sutherland, A. 2013. "The Role of Theatre and Embodied Knowledge in Addressing Race in South African Higher Education." Studies in Higher Education 38 (5): 728-740. doi:10.1080/03075079.2011.593620.

Svinicki, M. D., and N. M. Dixon. 1987. "The Kolb Model Modified for Classroom Activities." College Teaching 35 (4): 141-146. doi:10.1080/87567555.1987.9925469.

Treby, E., I. Hewitt, and A. Shah. 2006. "Embedding 'Disability and Access' Into the Geography Curriculum." Teaching in Higher Education 11 (4): 413-425. doi:10.1080/1356 2510600874169.

United States Department of Education. 2013. Accessibility and Universal Design. Office of Vocational and Adult Education. Accessed February 24, 2013. http://www2.ed.gov/about/ offices/list/ovae/pi/AdultEd/disaccess.html\#3.

Watchorn, V., H. Larkin, S. Ang, and D. Hitch. 2013. "Strategies and Effectiveness of Teaching Universal Design in a Cross-Faculty Setting." Teaching in Higher Education. doi:10.1080/13562517.2012.752730.

Wilson, M. E. 2004. "Teaching, Learning and Millennial Students." New Directions for Student Services 2004 (106): 59-71. doi:10.1002/ss.125.

Woodcock, A. 2007. "Ergonomics, Education and Children: A Personal View." Ergonomics 50 (10): 1547-1560. doi:10.1080/00140130701587384.

Zoltowski, C. B., W. C. Oakes, and M. E. Cardella. 2012. "Students' Ways of Experiencing Human-Centered Design." Journal of Engineering Education 101 (1): 28-59. doi:10.1002/ j.2168-9830.2012.tb00040.x. 